\title{
CONFLITOS TRABALHISTAS NAS “'TERRAS DO AÇÚCAR”: Zona da Mata Pernambucana (Anos 1960)
}

\author{
LABOR DISPUTES IN SUGAR LAND: \\ Zona da Mata Pernambucana in the 1960s
}

José Marcelo Marques Ferreira Filho*

\begin{abstract}
Resumo: Direito e Justiça do Trabalho para os assalariados rurais são recentes no Brasil. Da abolição da escravidão aos anos 1960, tais trabalhadores permaneceram legalmente invisíveis. A conquista dos direitos trabalhistas foi singular para os proletários rurais. Este artigo discute formas de usos do Direito e Justiça do Trabalho pelos canavieiros de Pernambuco nos primeiros anos após a promulgação do Estatuto do Trabalhador Rural e criação de Juntas de Conciliação e Julgamento na zona canavieira do Estado (ambos em 1963). Discussões sobre ganhos e perdas na Justiça cedem lugar a uma análise pormenorizada das ações dos trabalhadores, seus limites de possibilidades e alcance de suas estratégias. Seus atos de mobilização, individuais e coletivos, num território particularmente violento, refletiam ao mesmo tempo sua capacidade de ação, mas também sua miséria perene.
\end{abstract}

Palavras-chave: Proletários Rurais; Conflitos Trabalhistas; Justiça do Trabalho; Zona da Mata Pernambucana.

Abstract: Labour Law and Justice for rural workers in Brazil are recent. The abolition of slavery to the 1960s, these workers remain legally invisible. The conquest of labor rights was unique to the rural proletarians. This article discusses ways to use the Labour Law and Justice of Pernambuco sugar cane by the first years after the enactment of the Rural Worker and creation of Boards of Conciliation and sugarcane in the area of the state (both in 1963). Discussions about gains and losses in the courts give way to a detailed analysis of the actions of workers, their possibilities and limits of their range of strategies. His acts of advocacy, individual and collective, in a particularly violent area, reflecting both their capacity for action, but also enduring their misery.

Keywords: Rural Workers; Labor Dispute; Labor Court; Zona da Mata Pernambucana.

(recebido em $1^{\circ}$ de maio de 2012; aprovado em $1^{\circ}$ de junho de 2012)

A história social do trabalho vem se confundindo, em muitas ocasiões, com a história da classe operaria urbana. Apesar da significativa ampliação temática dessa linha de pesquisa, desde os anos $1980,{ }^{1}$ as relações de trabalho no campo configuram, para a maior parte da academia, horizontes timidamente atingidos. Os estudos acerca dos trabalhadores rurais, pósabolição $^{2}$ - suas formas de resistência no trabalho e na Justiça, condições de vida e saúde - são ainda uma temática pouco frequentada pela História Social. Ademais, discussões genéricas sobre as relações entre trabalhadores e patrões têm permitido generalizações infrutuosas. Muitos estudos perdem de vista a premissa básica do saber do historiador, qual seja: os processos históricos se diferenciam no tempo e no espaço. A análise das conjunturas

\footnotetext{
" Doutorando em História (UFPE). Orientadora: Prof. Dr. Christine Rufino Dabat. Bolsista CAPES.

${ }^{1}$ CHALHOUB, Sidney \& SILVA, Fernando Teixeira da. "Sujeitos no imaginário acadêmico: escravos e trabalhadores na historiografia brasileira desde os anos 1980". In: Cadernos AEL: trabalhadores, leis e direitos. Campinas: UNICAMP/IFCH/AEL, v.14, n.26, 2009, pp. 15-46.

${ }^{2} \mathrm{~A}$ tendência da maior parte da historiografia foi a de distinguir escravos e trabalhadores.
} 
específicas que distinga campo(s) e cidade(s) tem sido abandonada em detrimento de discussões sobre termos e conceitos fora de lugar.

O intenso debate a respeito da formação da classe trabalhadora no Brasil excluiu os assalariados agrícolas da história. A influência negativa do mundo rural na formação da classe não foi devidamente contestada. Como que possuindo um estatuto de inferioridade por residirem no campo (daí a ideia geral de que todos os trabalhadores rurais são camponeses, mesmo os assalariados), os assalariados rurais pareciam alienados de seu papel histórico impulsionado pela consciência de classe comum apenas aos operários - trabalhadores urbanos de categorias específicas. Haja vista o longo período que a historiografia levou para reconhecer os escravos enquanto trabalhadores, nada fora do normal que os rurais fossem destituídos de consciência de classe e incapazes de ações coletivas e revolucionárias. Mesmo as grandes mobilizações de trabalhadores rurais no Brasil através das Ligas Camponesas e Sindicatos de Trabalhadores, nas décadas de 1950 e 1960, não parecem ter Ihes inserido na história enquanto sujeitos ativos.

As discussões sobre o papel do Estado e os conflitos de classe na Justiça do Trabalho compõem outra problemática das grandes generalizações. Com as 'novas' tendências interpretativas no campo da história social, o peso da balança parece ter se invertido. A visão geral de que os trabalhadores eram sempre dominados e até submissos à classe patronal, cedeu lugar a interpretação oposta que admite quase tudo como conquistas trabalhistas. Tornouse tentador querer enxergar, sempre, que a classe trabalhadora possuiu um papel ativo-positivo no curso de qualquer história. Em algumas realidades específicas, entretanto, os limites de possibilidades de ação, aliados a um sofisticado modelo de exploração, sobrepujaram a liberdade da maior parte dos trabalhadores, mesmo sob diversas formas de resistência. É o caso específico dos conflitos trabalhistas na zona canavieira de Pernambuco. Esse artigo busca tecer algumas considerações no intuito de delimitar o alcance interpretativo no campo da história social do trabalho. Seu propósito específico é mostrar que mesmo resistindo por meio de reclamações na Justiça, os trabalhadores do açúcar encontravam limites históricos na sua atuação e conquistas.

A história social do trabalho nas plantações açucareiras no Nordeste do Brasil é singular. Em nenhum outro lugar, em todo o território nacional, um grupo tão reduzido de empresas controlou, com inegável liberdade prática, a força de trabalho de um número tão elevado de seres humanos. Semi-fechadas, longe dos centros urbanos e controladas por forças armadas de milícias privadas, as plantações açucareiras criaram uma sociedade do trabalho sobre a qual as vidas de homens e mulheres eram moldadas. A maior parte desses indivíduos, cujos antepassados haviam sido escravos na lavoura canavieira, viviam para o trabalho, embora a 
inversão da expressão também seja verdadeira (trabalhavam para viver). Tudo em suas vidas se relacionava diretamente com o trabalho que executavam desde muito cedo: i) a casa em que moravam; ii) os alimentos que consumiam; iii) a água que bebiam; iv) as roupas que usavam; v) o ritmo, intensidade e jornada de seus trabalhos; $v i)$ seu tempo de descanso e lazer etc. 0 trabalho compunha o cotidiano de vida desses "homens esquecidos": i) acordavam para trabalhar; ii) se alimentavam para trabalhar; iii) trabalhavam; iv) dormiam para descansar e trabalhar no dia seguinte. A influência que as usinas e engenhos exerciam sobre a vida dessas populações era quase absoluta.

\begin{abstract}
"Essas pessoas não eram agricultores, para quem a produção de commodities agrícolas fosse um negócio, nem eram camponeses, lavradores de terra que as possuísse ou pudesse tratar como sua, como parte de um modo diferente de vida. Eles eram trabalhadores agrícolas que não possuíam nem terra nem qualquer propriedade produtiva, e que tinham de vender seu trabalho para comer. Eles eram assalariados que viviam como operários, que trabalhava nas fábricas no campo, e quase tudo o que precisavam e usavam compraram do armazém. Quase tudo vinha de outros lugares: tecidos e roupas, sapatos, blocos de anotação, arroz, azeite de oliva, materiais de construção, remédios. Quase sem exceção, o que consumiam outra pessoa tinha produzido."3
\end{abstract}

Mesmo após a abolição da escravidão no Brasil, em 1888, o domínio da agroindústria açucareira impediu que a maior parte dos antigos escravos tivesse acesso a terra. Transformados em proletários plenos ("proletários rurais" na expressão de Sidney W. Mintz), no sentido de que não possuíam meios de produção além de sua própria força de trabalho, os trabalhadores rurais (ex-escravos) da cana dispunham de poucas alternativas fora dos limites da agroindústria açucareira. $O$ regime de morada, que se generalizou no século $X X$, permitiu que os proprietários de terras exercessem um duplo domínio sobre aqueles que habitavam em seus limites. Primeiro, porque eram obrigados a prestar serviços fisicamente penosos em troca de moradia cedida e alimentos e, depois, porque moravam nos locais de trabalho.

Direito e Justiça do Trabalho para os assalariados rurais são recentes no Brasil. Da abolição da escravidão aos anos 1960, tais trabalhadores permaneceram legalmente invisíveis. A conquista dos direitos trabalhistas foi singular para os "proletários rurais". Em primeiro lugar, sua exclusão expressa dos benefícios prescritos na Consolidação das Leis do Trabalho (CLT). Depois, o atraso em vinte anos para a promulgação do Estatuto do Trabalhador Rural (ETR) em 1963. A herança escravista de concentração de terra, violência e jornadas de trabalho extenuantes, aliada a uma recente experiência democrática no país (pós Estado Novo), levou

\footnotetext{
${ }^{3}$ MINTZ, Sidney W. Sweetness and Power: the place of sugar in modern history. New York: Viking Penguin, 1985, p.
} xxii. 
milhares de trabalhadores - primeiramente no Nordeste e em seguida em todo o Brasil - a se organizarem em Ligas Camponesas e Sindicatos de Trabalhadores Rurais nas décadas de 1950 e 1960. Diante da agitação das classes ditas perigosas, a crescente demanda por reforma agrária e melhores condições de trabalho e sob forte pressão internacional, após a Revolução Cubana, o Estado brasileiro decidiu assumir o controle e estabelecer os limites do conflito. Após vinte anos de atraso e vazio jurídico em relação aos trabalhadores da indústria, foi promulgado 0 ETR. A mobilização dos trabalhadores nesses anos de redemocratização foi fator essencial para a consolidação desses direitos. Nas palavras de Manuel Correia de Andrade:

\begin{abstract}
"O Estatuto se limitava a levar ao campo os direitos que já eram desfrutados pelos trabalhadores urbanos, muitos deles, já consagrados pela CLT, em 1943, mas ainda não aplicados. 0 Estatuto do Trabalhador Rural levava ao campo 0 direito de salário mínimo, a férias anuais remuneradas, ao repouso semanal, ao aviso prévio e a indenização em caso de demissão etc. Dava, também, o direito de os trabalhadores se organizarem em sindicatos iguais aos urbanos, registrados no Ministério do Trabalho. Não era fácil a aplicação da lei no meio rural, ante a complexidade e diversidade das formas de relações de trabalho."4
\end{abstract}

Também em 1963, na Zona da Mata de Pernambuco, os municípios de Jaboatão, Palmares, Escada, Nazaré da Mata e Goiana receberam as primeiras Juntas de Conciliação e Julgamento (JCJ). Em novembro do mesmo ano, durante o primeiro Governo de Miguel Arraes, após uma grande greve iniciada pelos cortadores de cana, foi realizado o Acordo do Campo entre usineiros, fornecedores de cana e representantes da classe trabalhadora, mediados pela Delegacia Regional do Trabalho. Esse acordo criou a chamada Tabela de Tarefas, na qual discriminava o salário equivalente a cada tipo de serviço na cultura da cana, desde a limpa de mato até o corte, melhorando, embora por pouco tempo, a remuneração dos canavieiros. Segundo Henrique Levy:

\footnotetext{
"Documento irrefutável - Diário do Congresso dos Estados Unidos (The Congressional Record) a partir de 1962 e no decorrer dos anos sessenta assinada que foi a pressão do senado dos Estados Unidos sobre o Instituto do Açúcar e do Álcool, do Brasil, que levou os usineiros do Nordeste a concordarem em remunerar um pouco melhor 0 cortador de cana, o 'camponês' de Pernambuco." ${ }^{5}$
}

No caso específico de Pernambuco, o "Tempo de Arraes" 6 foi o momento - em toda a história dos assalariados da cana - em que os trabalhadores foram mais bem remunerados. ${ }^{7} \mathrm{~A}$

\footnotetext{
${ }^{4}$ ANDRADE, Manuel Correia de. Lutas Camponesas no Nordeste. $2^{\text {a }}$ Ed. SP: Ática, 1989, p. 57.

5 LEVY, Henrique. "Os Acordos do Campo de Miguel Arraes: notas sobre alianças de classe na história contemporânea”. In: Clio: Revista do Curso de Mestrado em História. Recife: UFPE, n. 10, 1988, p. 124.

${ }^{6}$ CALLADO, Antônio. Tempos de Arraes: a revolução sem violência. $3^{\circ}$ Ed. RJ: Paz e Terra. 1980.
} 
partir do ETR, das JCJs instaladas na Zona da Mata, e, sobretudo da "Tabela de Tarefas", os trabalhadores rurais, além de uma lei específica para reger suas relações empregatícias, também teriam a disposição tribunais da Justiça do Trabalho. Entretanto, a "violência endêmica", nas palavras de Anthony Pereira, era o alicerce sobre o qual se sustentava todos os estratagemas da classe patronal. Embora justificadas pelos proprietários como "raras falhas de caráter", por parte de alguns maus patrões, ou ainda "legítima defesa dos proprietários", a violência, de fato, compunha um dos elementos que também afetava o nível de remuneração dos trabalhadores.

\begin{abstract}
"Não existia reclamação, não existia nada. [...] E se reclamava, botava para fora sem direito a nada."8

"Tinha que ficar caladinho. Porque eles não tinham o que fazer. Tinha que se a sujeitar àquilo, não era? Porque naquele tempo, se ele fosse arengar morria. Porque naquele tempo, a conversa era pouca; não tinha conversa: Não quer! Desocupe a casa, vinte e quatro horas!"9
\end{abstract}

O medo de reclamar refletia o perene clima de violência nas terras das usinas e engenhos. Não era raro trabalhadores serem ameaçados de morte ou de destruição de seus bens caso recorressem a Justiça. ${ }^{10}$ "Nesse sentido também, deve ser considerado a função econômica e social da violência patronal. Sua impunidade, garantida pelo Estado, asseguravaIhe um papel dissuasivo frente às reivindicações e queixas dos trabalhadores". 11

\begin{abstract}
"A violência dos proprietários de terra contra os trabalhadores e líderes sindicais ocorreu no Brasil porque os pobres rurais usaram a abertura proporcionada pela transição democrática para receber suas demandas reprimidas por terra e melhores salários. Isso instigou uma forte reação por parte dos proprietários rurais. A violência dos proprietários ampliou, porque o Estado não os punia; em vez disso, a força policial do Estado geralmente colaborava com sua autoridade. O Estado brasileiro, especialmente no Nordeste, onde o peso político dos proprietários era maior, não conseguia fazer cumprir a lei ou proteger o fraco da predação do forte."12
\end{abstract}

As implicações das medidas tomadas durante o primeiro mandato de Miguel Arraes são perceptíveis por vários ângulos. Doravante, a violência, antes desmedida e quase legalizada, foi

\footnotetext{
7 GONÇALVES, Fernando Antônio. "Condições de vida do trabalhador rural na zona da mata de estado de Pernambuco - 1964". In: BOLETIM DO INSTITUTO JOAQUIM NABUCO DE PESQUISAS SOCIAIS. Ministério da Educação e Cultura, nº 15, Recife, 1966.

${ }^{8}$ Rosendo Vicente de Sales citado por DABAT, Christine Rufino. Moradores de Engenho: estudo sobre as relações de trabalho e condições de vida dos trabalhadores rurais na zona canavieira de Pernambuco, segundo a literatura, a academia e os próprios atores sociais. Recife: EdUFPE, 2007, p. 604.

9 João Francisco citado por DABAT, Christine Rufino. Moradores de Engenho... Op. Cit., p. 582.

${ }^{10}$ ANDRADE, Manuel Correia de. Lutas Camponesas no Nordeste. Op. Cit., p. 22.

${ }^{11}$ DABAT, Christine Rufino. Moradores de Engenho... Op. Cit., p. 604.

12 PEREIRA, Antony W. The End of the Peasantry: the rural labor movement in Northeast Brazil (1961 - 1988). University of Pittsburgh Press, 1997, p. 117.
} 
reduzida. Entretanto, as conquistas dos trabalhadores rurais, "que estavam se construindo, efetivamente, em uma classe social", ${ }^{13}$ durou curto espaço de tempo. Menos de quatro meses depois de aprovado o Acordo, o Golpe Militar de 1964 pôs fim ao "Tempo de Arraes".

As estratégias patronais de redução salarial, somadas ao descumprimento da legislação e falta de ação por parte do Estado fazia com que restassem poucas opções à classe trabalhadora. A violência patronal como dissuasão de lutar e fator econômico, era o elemento inibidor de reações: "uma das dimensões mais drásticas da violência patronal, o assassinato de trabalhadores, ocorria geralmente em situações de conflito de interesses, os plantadores se recusando a pagar os vencimentos legais e os trabalhadores tendo a 'ousadia', 'la folle témérité', de reclamar". ${ }^{14}$

Ainda assim, com salários que não satisfaziam as necessidades vitais de qualquer ser humano, vários trabalhadores da agroindústria da cana buscaram formas de resistência. Além da ajuda mútua, do apoio do sindicato e do recurso as greves, o Direito e Justiça do Trabalho, recém-instituídos para 0 homem do campo, foram amplamente acionados pela classe trabalhadora. Mesmo durante o regime militar, e sob a ameaça de violência para com toda a família, centenas de trabalhadores recorreram a Justiça em busca dos direitos conquistados.

\section{Ações dos trabalhadores da cana na Justiça (1964-1968)}

Sob um clima de violência e permanente medo, as alternativas no empenho de ter 0 problema salarial resolvido eram reduzidas. Greves eram meios arriscados e violentos, suas consequências poderiam ser desastrosas, justificando maior violência contra seus líderes, muito embora tenha ocorrido, mesmo sem o apoio da FETAPE, durante todo o período. Na década de 1960, a principal estratégia sindical adotada foi o incentivo ao recurso a Justiça do Trabalho.

Sem malabarismos linguísticos e dispensando tudo que aparente ser de mais obvio, os trabalhadores rurais da cana sobreviviam dia após dia. Seus ínfimos salários, pagos por diária, sobretudo, eram literalmente "salários de morte", como revelada o jornal A Liga, em 13 de novembro de 1962. Um dia sem pagamento poderia significar, em alguns casos, um dia de fome. Na visão de muitos trabalhadores, a Justiça, recentemente criada, poderia minorar seu estado de miséria extrema. Valia a pena tentar.

A honra era um dos elementos que poderia compor as motivações de parte dos trabalhadores. ${ }^{15} \mathrm{~A}$ possibilidade de reclamar na Justiça contra aqueles que historicamente

\footnotetext{
${ }^{13}$ ABREU E LIMA, Maria do S. Construindo o Sindicalismo Rural: lutas, partidos, projetos. Op. Cit., p. 61.

${ }^{14}$ DABAT, Christine Rufino. Moradores de Engenho... Op. Cit., pp. 667-673.

${ }^{15}$ MIRANDA, Moema Maria Marques de. Espaço de Honra e de Guerra: etnografia de uma Junta Trabalhista. Dissertação de Mestrado. RJ: UERJ, 1991.
} 
possuíam o poder de mando nas instituições políticas e sociais existentes, traria certa expectativa a uma classe esquecida. Poder ficar cara a cara com um representante da usina, que deveria prestar esclarecimentos perante um juiz, se revelava, no horizonte de parte dos trabalhadores, uma alternativa atraente. No mínimo poderia expor publicamente, e perante as autoridades, sua insatisfação. Para a classe patronal, por outro lado, as reclamações trabalhistas representavam uma ingratidão por parte dos trabalhadores, que não reconheciam a oportunidade de levar uma vida digna e honesta.

Entre 1964 e 1968, as Juntas de Conciliação e Julgamento de Escada e Palmares, recentemente instaladas, receberam reclamações de trabalhadores de toda a Zona da Mata Sul de Pernambuco. Um estudo detalhado com os processos abertos nesse período permitiu identificar 0 alcance dessa forma de resistência no tocante às condições de vida da classe trabalhadora rural. A agroindústria da cana de açúcar representou mais de $90 \%$ dos autos em ambas as juntas. A procedência da maior parte dos reclamantes pode ser ilustrada no mapa a seguir:

Figura 1: Mapa da área de abrangência real das Juntas de Conciliação e Julgamento de Escada e Palmares (19641968)

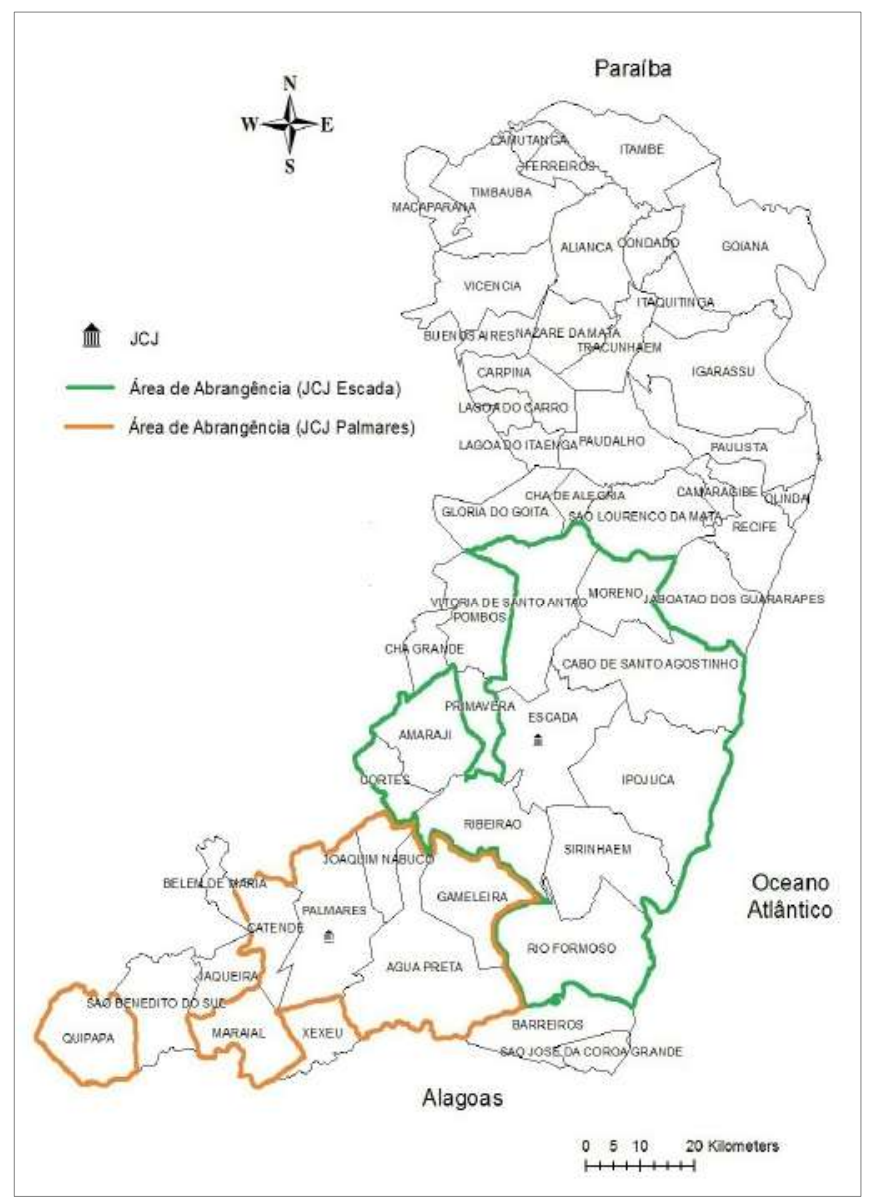

Fonte: Dados coletados a partir dos processos trabalhistas no acervo do TRT $6^{\circ}$ Região. 
$\mathrm{Na}$ Junta de Escada, cerca de $80 \%$ dos reclamantes eram do sexo masculino e não possuíam alfabetização. Os processos na Junta de Palmares possuíam a mesma proporção quanto ao sexo. 0 índice de analfabetos atingia 70\%. Embora semelhante em seu conjunto, no que toca a classe social dos que as procuravam, as Juntas possuíam singularidades quanto à natureza dos processos que recebiam (Gráfico 1 e 2).

Gráfico 1: Número de rescisões de contrato e reclamações trabalhistas no setor sucroalcooleiro em relação ao total de processos abertos na JCJ de Escada entre 1964 e 1968

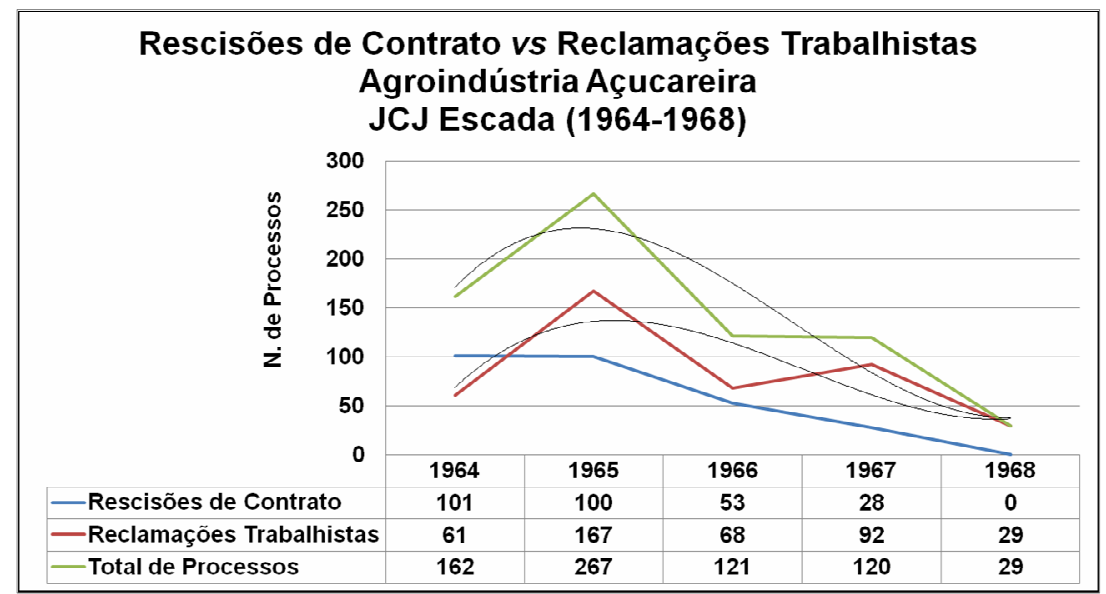

Fonte: Dados coletados a partir dos processos trabalhistas no acervo do TRT $6^{\circ}$ Região.

Na Junta de Conciliação e Julgamento de Escada entre os anos 1964 e 1968, 60\% dos processos tratavam de reclamações trabalhistas. Os quarenta por cento restantes configuravam rescisões de contrato, cujo único objetivo era a homologação da Justiça do Trabalho. 0 maior número de processo foi aberto em 1965, ano com mais reclamações. As linhas de tendência indicam certa simetria entre o total de processos e o número de reclamações. Nos primeiros três anos a proporção seguia praticamente a mesma, com pouca variação no ano seguinte. Em 1968 as reclamações representaram $100 \%$ dos autos.

A Justiça do Trabalho de Palmares possuía uma demanda nitidamente particular. Embora 1965 também tenha sido o ano de maior numero de autos, noventa e cinco por cento dos processos abertos tratavam de homologação de rescisão de contrato de trabalho. Nesse caso, diferentemente de Escada, as linhas de tendência revelam uma simetria e proximidade quase absoluta, entre o total de processos e o número de Rescisões de Contrato, ao longo de todos os anos (Gráfico 2). 
Gráfico 2: Número de rescisões de contrato e reclamações trabalhistas no setor sucroalcooleiro em relação ao total de processos abertos na JCJ de Palmares entre 1964 e 1968.

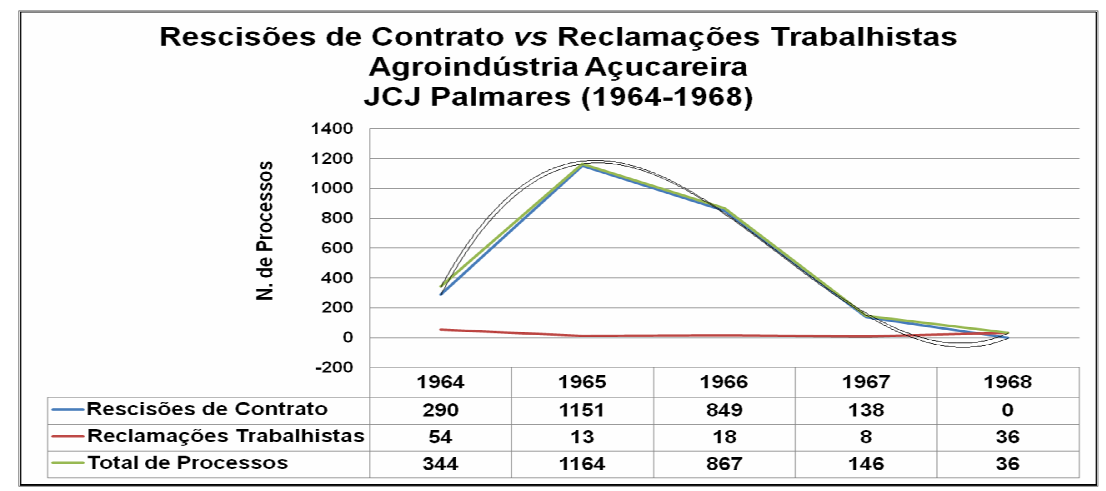

Fonte: Dados coletados a partir dos processos trabalhistas no acervo do TRT $6^{\circ}$ Região.

Nas rescisões, uma simples assinatura do juiz da Junta bastava para produzir os efeitos legais, e por fim ao contrato de trabalho. Não era preciso o envio de cartas de notificação, nem agenda de Audiências de Instrução e Julgamento. Em um único dia se poderiam homologar dezenas de rescisões de contrato, e, de fato, ambas as Juntas funcionaram dessa forma no período em questão.

A maior parte dos processos detalhava o tipo de rescisão de contrato: i) AMIGÁVEL (escrito em letras capitais) e/ou ii) por "livre e espontânea vontade" do trabalhador. Em ambos os casos os trabalhadores recebiam apenas uma quantia irrisória, quando não, diziam sair do emprego bem pagos e satisfeitos, mesmo sem nada receber. Os motivos pelos quais se poderia solicitar a rescisão contratual dependiam do tipo de formulário que o trabalhador era persuadido a assinar. Documentos produzidos em série, cujo conteúdo tratava de pedido de demissão do trabalhador, eram comuns em toda a zona canavieira.

O fato de tratar-se de formulários previamente concebidos, como comprova a estrutura mimeografada da maior parte deles, poderia não ser o bastante para afirmar que usinas e engenhos produziam falsos documentos. Tampouco que apenas um terço dos trabalhadores que os assinaram sabia ler e escrever. Talvez, o cuidado em acrescentar que se tratava de rescisão por "livre e espontânea vontade" e "correspondendo a interesse de ordem particular" do trabalhador, fosse suficiente para evitar comentários inoportunos. A ausência expressa de "coação" e "constrangimento", talvez bastasse para configurar uma verdadeira tomada de decisão do trabalhador, que "pretendia viajar para fora do município".

$\mathrm{Na}$ Junta de Escada, em um único dia, 11 de maio de 1965, mais de quarenta trabalhadores "solicitaram" sua rescisão de contrato assinando termos idênticos. ${ }^{16}$ Todos eles, 
pertencentes à mesma usina em Ribeirão, foram homologados. Apenas a metade dos trabalhadores sabia ler e escrever. Na Junta de Palmares não era diferente: outras usinas utilizavam formulários semelhantes, onde o trabalhador declarava que "nada mais [tem] a reclamar em tempo algum, sob qualquer fundamento ou pretexto".

Bem estruturados pelas usinas para evitar inconvenientes posteriores, os formulários desafiam as mentes que procuram o verdadeiro motivo por trás da simples assinatura. Na lógica empresarial capitalista, evitar despesas com indenização por tempo de serviço, antes que 0 trabalhador completasse um ano no emprego, fazia todo o sentido. Outros (Figura 2) eram mais detalhados, onde o trabalhador supostamente se reconheceria "sem direito a aviso prévio, indenização, $13^{\circ}$ mês de salário, repouso remunerado, férias, extraordinários, salários retidos, diferença salarial, dias santos ou outro qualquer direito, nada mais tendo a reclamar, seja sob que título for, em qualquer época, em juízo ou fora dele". A análise detalhada do processo ainda revela outros artifícios - bastante comuns - da classe patronal. A apenas um dia de se tornar empregado estável é persuadido a renunciar da própria estabilidade. Em outros casos os trabalhadores solicitavam a "bondade" da usina para ser dispensado do aviso prévio, depois de haverem declarado que saiam pagos e satisfeitos, sem nada receber. ${ }^{17}$

02390/65; 02391/65; 02392/65; 02393/65; 02394/65; 02395/65; 02396/65; 02397/65; 02404/65; 02406/65; 02407/65; $02408 / 65 ; 02413 / 65 ; 02414 / 65 ; 02415 / 65 ; 02416 / 65 ; 02417 / 65 ; 02418 / 65 ; 02419 / 65 ; 02420 / 65 ; 02421 / 65 ; 02422 / 65$. 17 Proc. 1239/66, JCJ de Palmares, acervo do TRT 6a Região. 
Figura 2: Termo de Rescisão de Contrato de Trabalho e Recibo de Dispensa mimeografado, Catende/PE

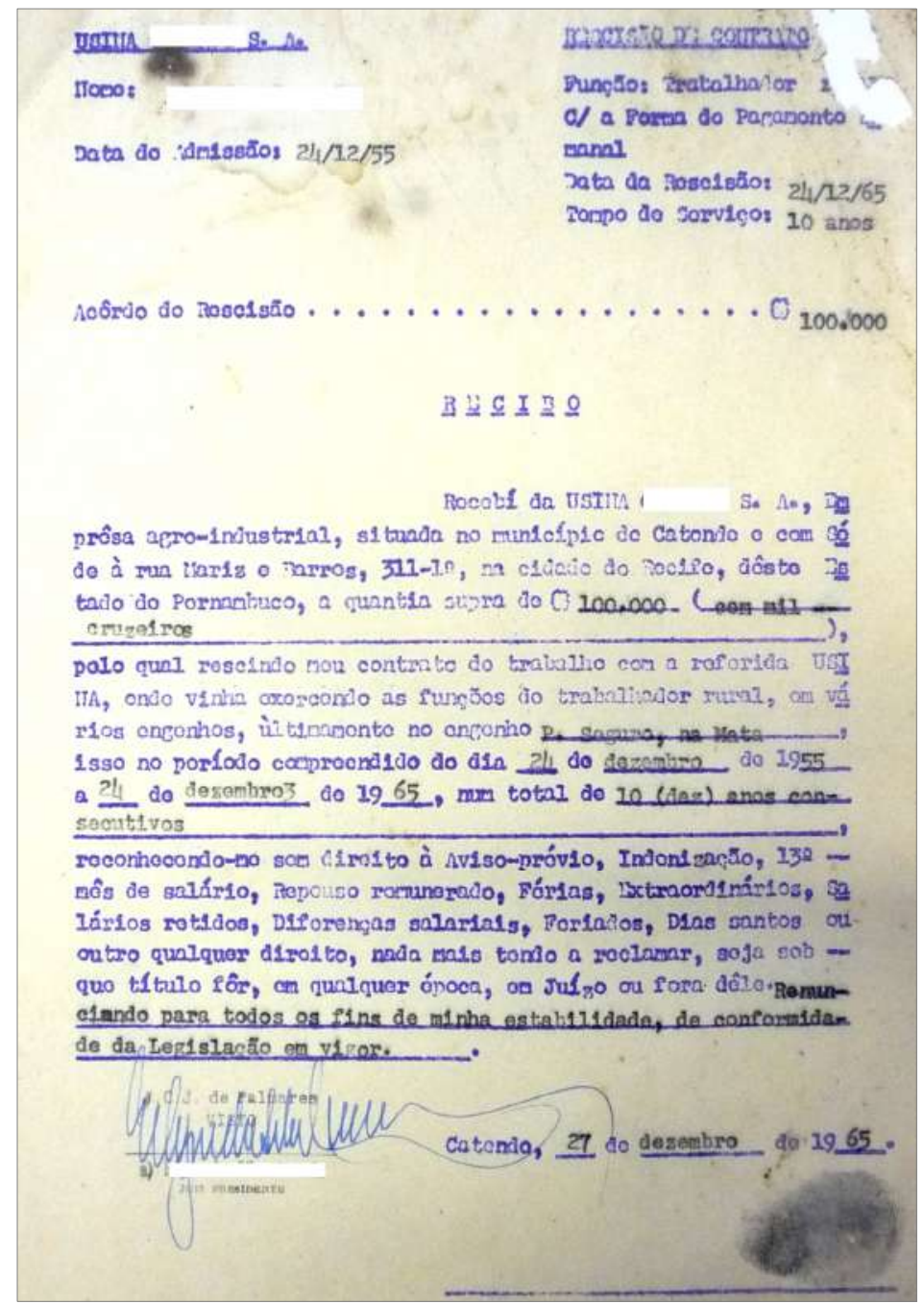

Fonte: Proc. 17/66, JCJ de Palmares, acervo do TRT 6a Região.

Não obstante ser prática comum das usinas, o próprio Poder Judiciário produzia Termos de Homologação de Rescisão de Contrato (Figura 3), onde o trabalhador pediria a renúncia da própria estabilidade. Isso quando o regulamento da Lei n $\mathrm{n}^{0}$ 5.107, de 13 de setembro de 1966, que dispõe sobre o FGTS, não tinha sido ainda aprovado. 
Figura 3: Termo de Homologação de Rescisão de Contrato de Trabalho mimeografado pela Justiça do Trabalho, JCJ de Palmares.

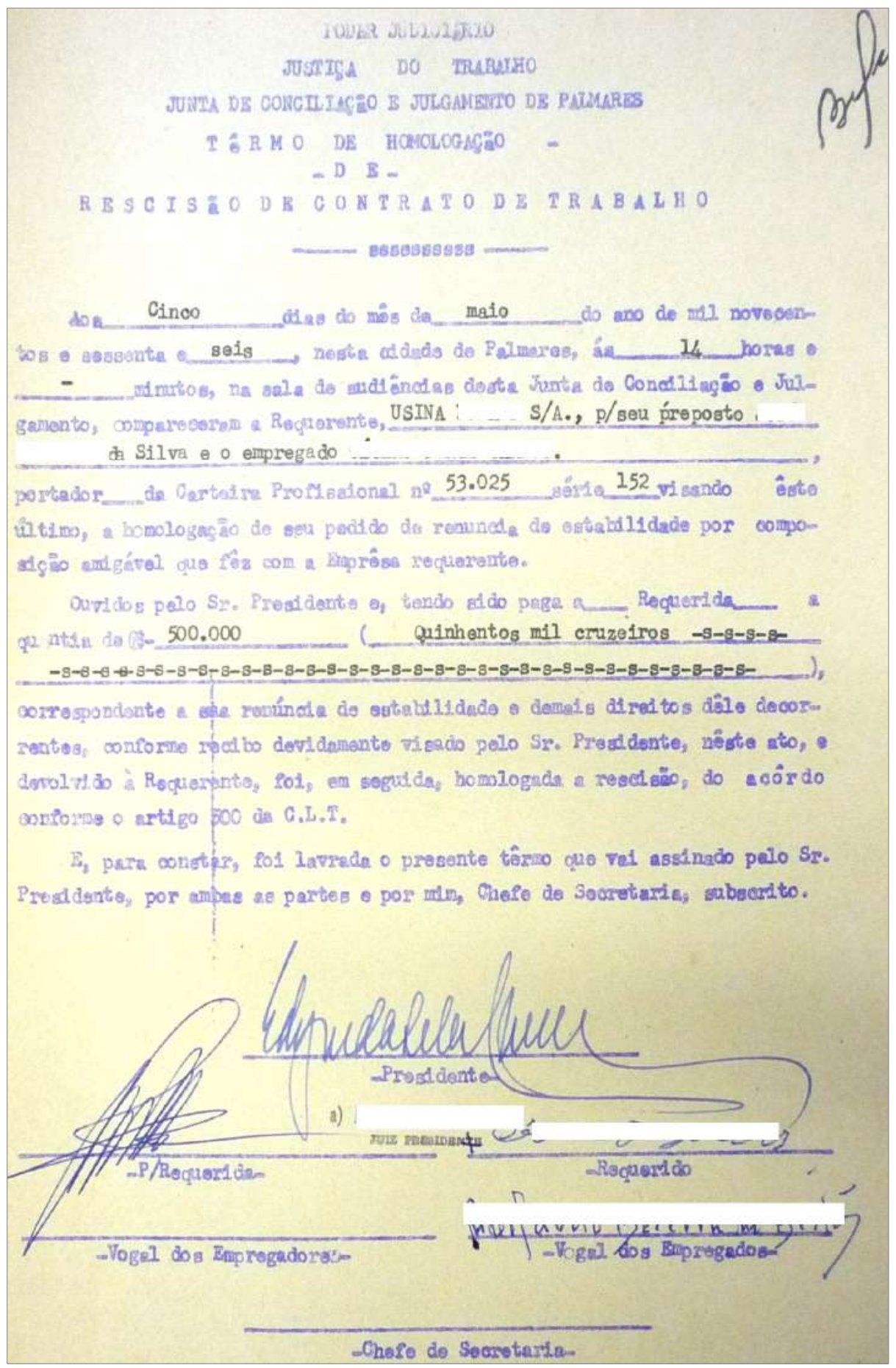

Fonte: Proc. 1538/66, JCJ de Palmares, acervo do TRT 6 a Região.

Todas essas maneiras de findar as relações com seus empregados acabavam por compor o arsenal de ferramentas criadas para evitar o cumprimento da legislação trabalhista. Para a classe patronal, esses documentos certamente seriam suficientes para provar sua honestidade e generosidade. A semelhança entre os documentos de distintos municípios revela 
um consenso entre os empregadores no sentido de pressionar a massa de trabalhadores, num ambiente particularmente violento.

Os empregados - ou, na maioria dos casos, já desempregados - que não aceitavam "renunciar" a seus direitos, assinando documentos forjados, ou haviam sido demitidos sem justa causa, arriscavam-se botando questão na Justiça do Trabalho. Em ambas as Juntas, as questões salariais configuravam nitidamente a quase totalidade dos direitos reclamados.

Ao longo dos anos, as reclamações feitas na Junta de Escada revelam certa regularidade. $O$ direito a férias era a reclamação mais frequente, seguido pelo $13^{\circ}$ salário e diferença salarial. Na maioria dos processos, como indicam as linhas de tendência, férias, $13^{\circ}$ salário e diferença salarial eram solicitados em conjunto. Em seguida, indenizações e aviso prévio que não passavam de um terço do total de processos reclamados.

Uma análise detalhada de cada processo permite discutir questões relevantes. A ideia de que a não observância da legislação trabalhista era normalmente praticada pela classe patronal canavieira, pode ser comprovada nos formulários de reclamação contra usinas, produzidos pelas Juntas. Até mesmo a Justiça do Trabalho reconhecia que a massa de canavieiros "sendo trabalhadores rurais", era "consequentemente, pobre nos termos da lei". ${ }^{18} \mathrm{De}$ fato, era a pobreza extrema - que deixava de alimentar o corpo já exausto pelo regime de trabalho - o motor imóvel que levava a maior parte dos reclamantes à Justiça do Trabalho. A inércia das autoridades públicas, quanto à fiscalização do cumprimento das leis, também alimentava o sistema.

\section{Formas de resolução das reclamações trabalhistas}

A maior parte das reclamações era rapidamente solucionada. Normalmente, audiências de vários processos eram marcadas para o mesmo dia. Nessa ocasião deveriam comparecer 0 reclamante e um representante da empresa reclamada, que, na maioria dos casos era seu preposto, juntamente com um dos advogados da usina. 0 trabalhador também poderia vir acompanhado do patrono ou representante sindical.

As audiências eram rápidas, na maioria dos casos. Quando as partes envolvidas não chegavam a um acordo - ínfima minoria dos casos - era marcada nova audiência. Alguns processos duravam mesmo vários anos, décadas, sem que o trabalhador pudesse ter seu caso solucionado em definitivo. Quando os juízes da Junta julgavam o processo contra a reclamada

\footnotetext{
${ }_{18}$ Proc. 2917/68, JCJ de Palmares, acervo do TRT 6ª Região.
} 
(casos atípicos em ambas as Juntas), as empresas poderiam recorrer da decisão: o que normalmente ocorria.

"Outro problema [...] era a lentidão da Justiça do Trabalho, onde as disputas entre patrões e empregados sobre assuntos como indenizacoes eram julgadas. Muitos líderes diziam que o tribunal era muito lento, podendo levar até 5 ou 6 anos para resolver o caso. Outros questionavam a imparcialidade dos juízes dos tribunais do trabalho, dizendo que eles eram da mesma classe social e geralmente tinham freqüentes contatos sociais com os proprietários." ${ }^{19}$

Durante esse período, o trabalhador era responsável por todas as suas despesas de deslocamento até as Juntas. Distância e elevados custos de transporte impediam-no, em muitos casos, de comparecer a audiência, levando ao arquivamento do processo. Como mostram os gráficos das sentenças, cento e sessenta e cinco reclamações foram arquivadas, em ambas as juntas.

Gráfico 3: Formas de resolução das reclamações trabalhistas contra usinas e engenhos na JCJ de Escada entre 1964 e 1968

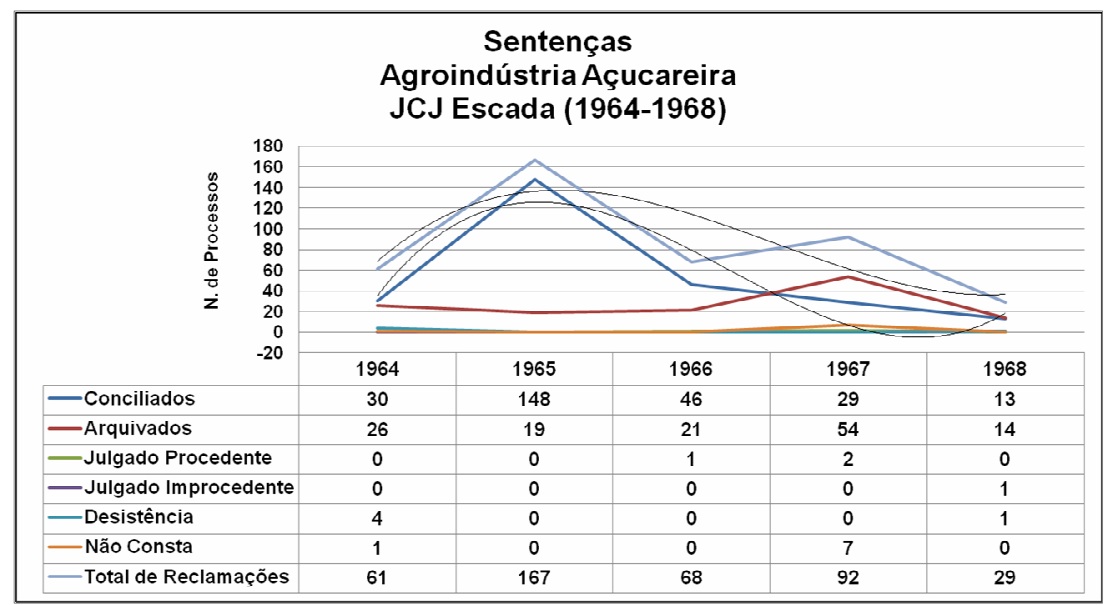

Fonte: Dados coletados a partir dos processos trabalhistas no acervo do TRT $6^{\circ}$ Região.

Gráfico 4: Formas de resolução das reclamações trabalhistas contra usinas e engenhos na JCJ de Palmares entre 1964 e 1968

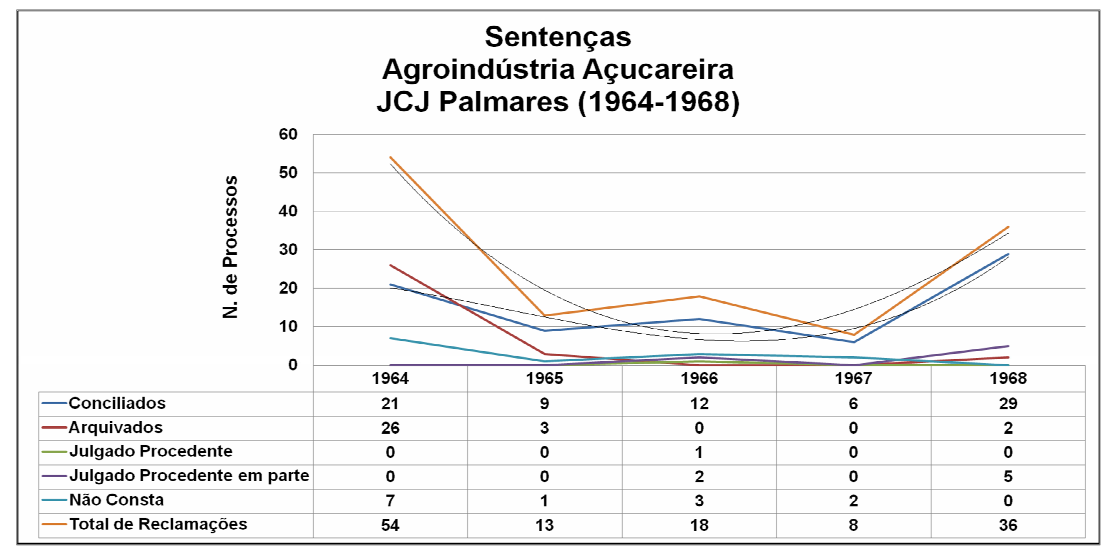

Fonte: Dados coletados a partir dos processos trabalhistas no acervo do TRT $6^{\circ}$ Região.

19 PEREIRA, Antony W. The End of the Peasantry: the rural labor movement in Northeast Brazil (1961-1988). University of Pittsburgh Press, 1997, p. 105. 
De fato, nos termos de arquivamento apenas consta que: "não tendo comparecido o reclamante, o processo deverá ser arquivado". O julgamento a revelia da reclamada (pelo não comparecimento da mesma a audiência) não ocorria por motivos óbvios: as usinas possuíam grande número de funcionários que poderia assumir o papel de preposto. Embora reflexos reais de impossibilidades financeiras e/ou viárias de deslocamento e transporte, tais problemas não eram causa exclusiva dos arquivamentos. Não declarados nos autos, os motivos e os meios pelos quais se "escolhia" não comparecer a audiência passava, sobretudo, pela ameaça de violência e coação. O silêncio, nesses casos, mais uma vez revela sua eloquência. Assim como o cuidado que as usinas tinham em deixar claro, nas rescisões de contrato produzidas em série, a ausência de "coação e constrangimento", expõe, em filigranas, um ato de violência dissimulada.

As audiências revelavam ainda outros casos. Na Junta de Escada, não obstante a distância, o custo e o tempo gasto em deslocamento, no dia da audiência alguns trabalhadores "escolheram" desistir da reclamação e não levar a lide adiante. ${ }^{20}$ Para tomar como exemplo, 0 processo 60/64 foi aberto por um trabalhador com treze anos de serviço que, depois de recuperado de um acidente de trabalho sofrido a serviço de uma usina "pede, por ser estável, sua reintegração, com os direitos e vantagens de sua categoria, salários vencidos e vincendos e férias jamais gozadas". Na audiência: "[...] Presentes as partes, o reclamante pessoalmente e a reclamada representada pelo seu preposto Sr. [...], relatou o Sr. Presidente o processo e com a palavra o reclamante declarou que desistia da presente reclamação". No processo 1459/64 a trabalhadora rural "declarou [...] que começou a trabalhar para a reclamada no ano de 1922, sendo demitida sem justa causa no dia 11 de agosto de 1964. Percebia salário diário de Cr\$1.100,00. Reclama: Indenização, por tempo de serviço, aviso prévio, $13^{0}$ mês, férias". Na audiência: "Presentes as partes [...] o reclamante declarou que desistia da presente reclamação $[\ldots] "$.

Desistir da reclamação talvez não seja a questão mais importante a ser discutida nesses processos. $\mathrm{O}$ ato escusado de se deslocar ao Tribunal para fazê-lo, sim. Talvez a ameaça de demissão dissuadisse-os. Não era o caso: todos os reclamantes já haviam perdido seus empregos. Em tese, continuar na lide não Ihes causaria prejuízo algum. Porque não, simplesmente, faltar à audiência levando ao arquivamento? Não obstante as atitudes controversas dos trabalhadores, a própria Justiça do trabalho pré-fabricava Atas de Audiência declarando que "o reclamante disse que desistia da reclamação" (Figura 4).

20 JCJ de Escada processos: 060/64; 1441/64; 01459/64; 01522/64 e 431/68. 
Figura 4: Ata de Audiência impressa produzida em série pela Justiça do Trabalho, JCJ de Escada

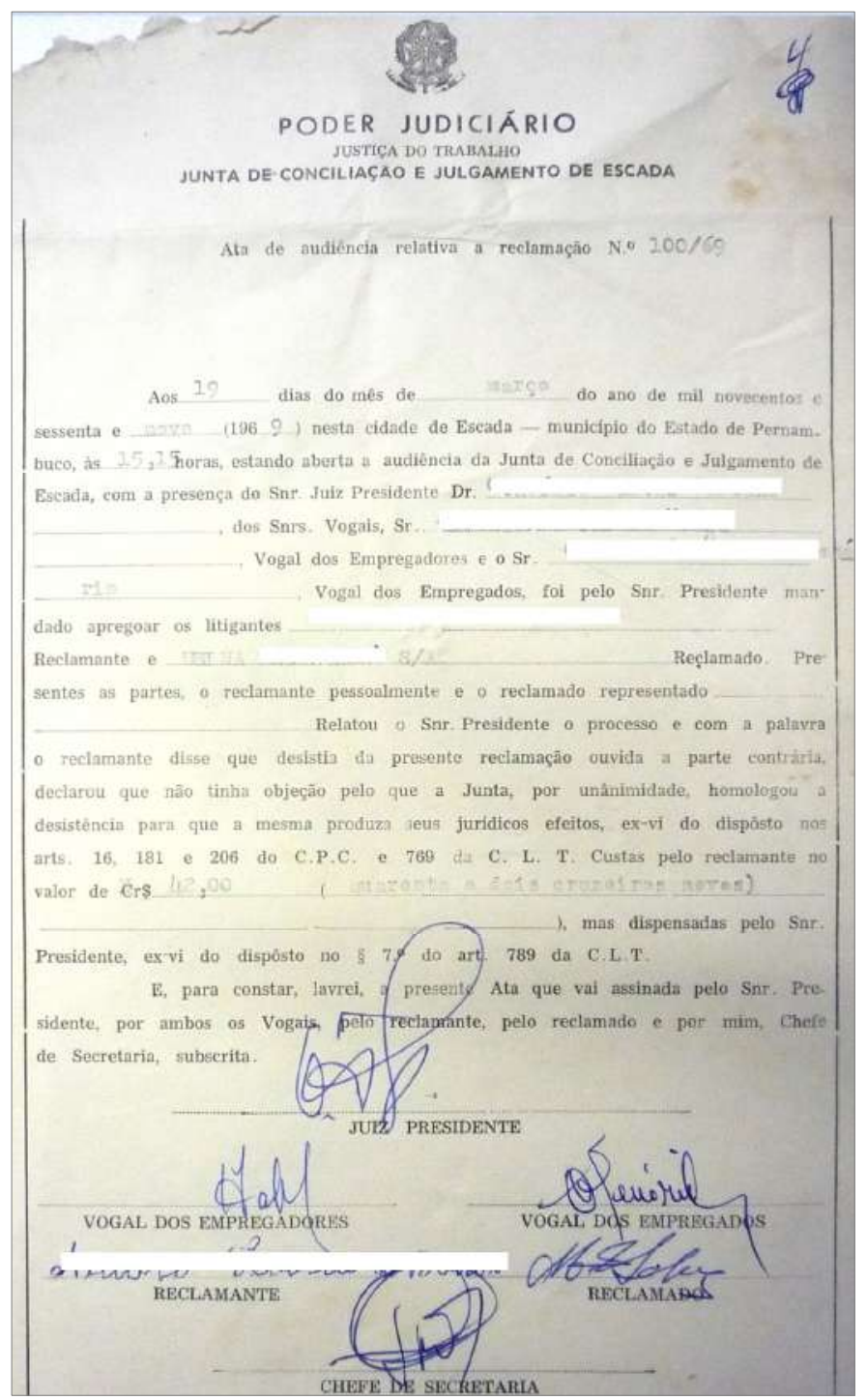

Fonte: Proc. 100/69, JCJ de Escada, acervo do TRT 6a Região.

\section{Conciliações: quando a Justiça legaliza o ilegal}

Os gráficos com as sentenças das reclamações (Gráficos 3 e 4) nas Juntas de Escada e Palmares mostram seu funcionamento: os processos conciliados representavam sessenta por cento, ou mais, dos casos. Na Junta de Escada, os primeiros três anos marcam uma nítida simetria e proximidade entre o número total de reclamações e conciliações. Já em 1967 e 1968 os arquivamentos ultrapassam as conciliações. Em Palmares, de forma semelhante, a maior parte das reclamações terminava em conciliações. Exceto em 1964, ano de maior numero de arquivamentos, aproximadamente $50 \%$. Os processos julgados representavam "falhas" num sistema instituído para conciliar.

O princípio da conciliação regia o funcionamento das Juntas. Sua composição de dois membros e um juiz presidente era encarregada de fazer a proposta de acordo. 0 julgamento da 
reclamação apenas era realizado caso as partes não entrassem em composição amigável. Em termos jurídicos, as conciliações "eliminavam" o conflito entre patrões e empregados. Em termos práticos, homologavam a superexploração da mão de obra, mantendo sua remuneração em níveis miseráveis.

Parte do ordenamento jurídico da Justiça do Trabalho, as conciliações eram consideradas justas, por isso mesmo, expressão do êxito das Juntas em dirimir conflitos. Seu percentual, em relação ao total das reclamações deveria compor os relatórios mensais das Juntas, assim como: o número de audiências realizadas e seu tempo médio em relação à entrada do processo; o número de processos julgados; de reclamantes atendidos etc. A liberdade das partes (em aceitar, ou não, um acordo) era o argumento pelo qual sua prática ordinária era justificada. Matematicamente - para o Judiciário: eficiência da Justiça do Trabalho e número de conciliações eram variáveis diretamente proporcionais.

Afirmar, puramente, que a maior parte das reclamações findava em conciliações, esconde em si seus detalhes. O cálculo era simples: a média das diferenças entre os valores demandados nos Termos de Reclamação e os valores acordados nos Termos de Conciliação era aproximadamente vinte por cento. ${ }^{21}$ A particularidade dos episódios isolados, cuja conciliação ultrapassava cinquenta por cento do valor reclamado, não anula o efeito negativo sobre as condições de vida e saúde da classe trabalhadora. Em alguns casos os trabalhadores recebiam menos que dois por cento dos direitos que, por lei, já Ihes pertenciam.

De fato, trata-se de um termo grandiloquente cujo belo significado linguístico escamoteia a realidade em função de cifras, percentagens que em quase nada relatam a alacridade de seus beneficiados imagináveis. Logicamente, se todos os direitos assegurados ao trabalhador fossem cumpridos - ou o serviço público encarregado da fiscalização do trabalho funcionasse em consonância com seus propósitos prescritos - o princípio da conciliação não chegaria a existir. Porém, no momento mesmo de gestação do Direito do Trabalho moderno ele foi pensado, compondo, desde então, seu alicerce teórico.

As queixas de que os trabalhadores reclamavam além do que lhes era devido, compunham a linha argumentativa da classe patronal que supostamente justificaria suas diminutas propostas de acordo. Se verdadeira, talvez esse raciocínio contribuísse para tirar 0 trabalhador rural da lista dos povos primitivos e pouco evoluídos. Ele era capaz de fazer as operações matemáticas básicas. Sabendo que a conciliação representava um prejuízo, talvez seu raciocínio conservasse uma lógica sofisticada: reclamar a mais para receber o que de fato

21 A média das diferenças entre os valores reclamados e acordados ao longo dos anos são: 1964 (21\%); 1965 (10\%); 1966 (26\%); 1967 (19\%) e $1968(30 \%)$. 
Ihes era devido. Entretanto, a longa duração na história da zona canavieira de Pernambuco, tem espelhado as reais relações de poder no mundo do trabalho rural.

Se 0 argumento empresarial é equivocado, o que explicaria a maior parte dos acordos aceitos pelos trabalhadores? Talvez um anexim conhecido ajude a entender: "é melhor receber pouco do que receber nada" ou "vale mais um pássaro na mão que dois voando". Na fala dos próprios trabalhadores a explicação é simples: "o trabalhador faz acordo por cansaço. Porque às vezes ele sabe que vai ganhar cem mil cruzeiros, mas passam-se os anos... então ele, para receber com dois meses, três, faz acordo de receber quarenta, pelo menos não passa tanta fome". Os mecanismos que permitiam o grande número de adiamento das empresas, somados as necessidades imediatas da classe trabalhadora e as ameaças de violência, devem compor os fatores que induziam às conciliações.

\begin{abstract}
"Como os processos demoravam muito para serem julgados, recorria-se com frequência à conciliação, e, por ela, quem abria mão era sempre o trabalhador, na esperança de garantir um mínimo, quando não podia esperar pelo final do processo. Mesmo assim, existiam vitórias, particularmente quando o sindicato era ativo, dispunha de um bom advogado e os trabalhadores não se limitavam ante as ameaças e violências." 22
\end{abstract}

Longe de representar concessões recíprocas entre as partes, os Termos de Conciliação previam, de fato, renuncia unilateral de direitos adquiridos (Figura 5). A predisposição das usinas em não cumprir a legislação tinha respaldo nos Termos de Conciliação pré-fabricados pela Justiça, onde os reclamantes recebiam uma pequena quantia referente ao $13^{\circ}$ salário e "desistiam dos demais itens da reclamação". Nesses casos, os acordos pré-formatados pelas Juntas, também previam uma diminuição do tempo de serviço devidamente prestado pelo trabalhador. ${ }^{23}$ Em nome da falsa liberdade das partes, a Justiça do Trabalho arquitetava acordos ilegais.

\footnotetext{
22 ABREU E LIMA, Maria do S. Construindo o Sindicalismo Rural: lutas, partidos, projetos. Op. Cit., p. 128.

${ }^{23}$ Alguns exemplos: processo 2032/65 o reclamante começou a trabalhar em 13/09/1952 e teve sua carteira assinada para 30/04/1963; processo 2112/65 início em 24/06/1959 e assinatura em 5/10/1962; processo 2186/65 início em 1/09/1936 e assinatura em 12/10/1945; processo 2188/65 início em 15/02/1940 e assinatura em 10/10/1947; processo 2196/65 início em 10/10/1952 e assinatura em 12/10/1956.
} 
Figura 5: Termo de Conciliação impresso e produzido em série pela JT, JCJ de Escada

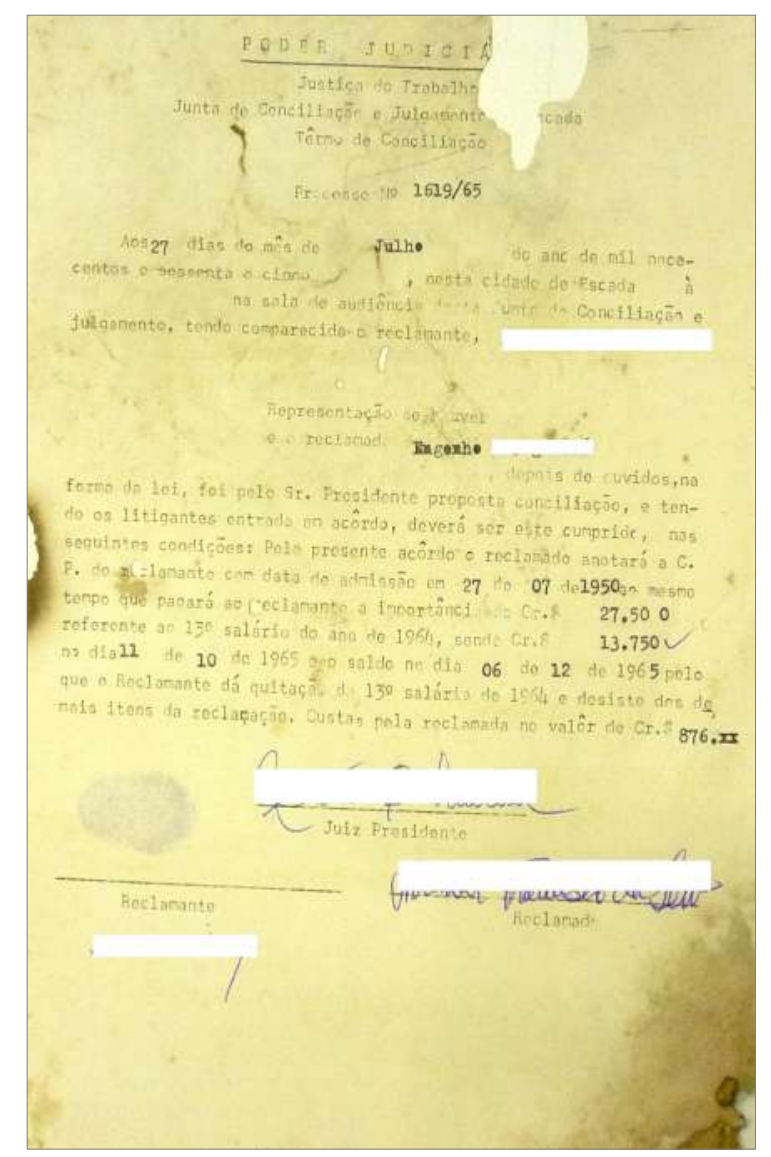

Fonte: 1619/65, JCJ de Escada, acervo do TRT 6ª Região.

Maior celeridade no funcionamento das Juntas (em número insuficiente para o montante de processos abertos) é, geralmente, o argumento dos magistrados que, supostamente, justificaria a reprodução desses documentos. A histórica dominação que a classe proprietária exercia sobre os serviços públicos - incluindo o Judiciário -, jamais é mencionada. Problemas na colheita da cana e no mercado interno e externo, que eventualmente pudessem afetar 0 comércio de açúcar e álcool, e que, consequentemente, justificaria os atrasos no pagamento do salário, também são desmascarados diante de um conjunto de provas e relatos:

\begin{abstract}
"Os proprietários acham que tem vantagem em não cumprir a legislação trabalhista, quer ver? Vamos fazer uma matemática simples: você tem mil trabalhadores, não paga o repouso aos mil trabalhadores, aí cem vão para a Junta e reclamam. Mesmo você pagando todas as multas, juros e etc. você não ganhou, pagando a cem e deixando de pagar a novecentos."24
\end{abstract}

Sobrevivendo na corda bamba da legalidade dos anos de chumbo, os Sindicatos de Trabalhadores Rurais concordavam, e até persuadiam seus associados, a aceitarem as propostas de conciliação, minúsculas que fossem. 0 gráfico abaixo mostra a perfeita simetria

${ }^{24}$ Rui Lopes, Juiz presidente da JCJ de Alegrete citado por MIRANDA, Moema Maria Marques de. Espaço de Honra e de Guerra: etnografia de uma junta trabalhista. Op. Cit., p. 235. 
entre o número total de reclamações, por meio dos Sindicatos, e conciliações. As linhas de tendência chegam a se justapor.

"Muitos trabalhadores se queixavam de que seus próprios advogados tentavam forçá-los a aceitar acordos com plantadores. Alguns trabalhadores também buscaram um acordo, porque eles viam quantos processos estavam à frente dos seus em pauta e como os tribunais eram lentos para se pronunciarem. Isso fez com que 0 acordo, em média, tivesse um nível bem abaixo da demanda inicial. Por seu lado, os dirigentes sindicais observavam que o grande número de processos exigia que eles passsassem quase todas as tardes no tribunal. Esses padrões se incorporaram na cultura dos tribunais, e a disposição dos trabalhadores para a JCJs permanecia sujeita à manipulação por parte dos empregadores." 25

Gráfico 5: Formas de resolução das reclamações trabalhistas iniciadas por intermédio dos sindicatos de trabalhadores contra usinas e engenhos na JCJ de Escada entre 1964 e 1968

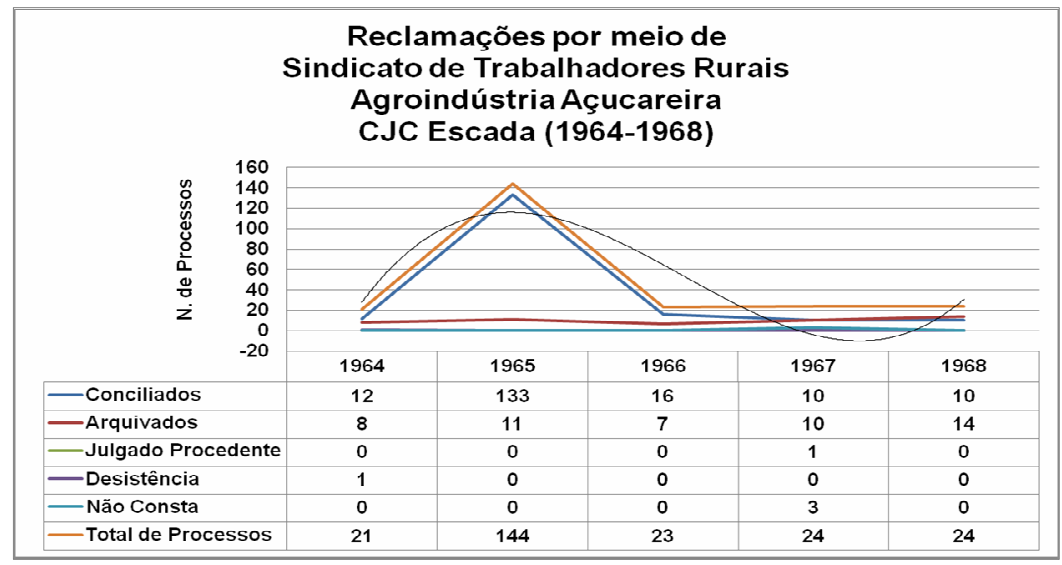

Fonte: Dados coletados a partir dos processos trabalhistas no acervo do TRT $6^{\circ}$ Região.

\section{O legado de permanência: "reclamava, mas não tinha jeito e aquilo ficava daquele jeito mesmo" 26}

$\mathrm{Na}$ contramão daqueles que defendem o ETR e as JCJs como revolucionários e transformadores, a análise cuidadosa do comportamento da classe patronal canavieira e da Justiça do Trabalho na Zona da Mata de Pernambuco revela profundas permanências na estrutura de dominação sobre a massa de assalariados.

Uma discussão pormenorizada do ETR permite perceber que sua redação se assemelhava a CLT, com algumas alterações. Suas alíneas, entretanto, não levaram em conta as profundas especificidades que as relações de trabalho e emprego no campo, bem como as tarefas realizadas, carregavam em si. Nesse ínterim, Caio Prado Junior concluiu que sua

${ }^{25}$ ROGERS, Thomas D. The deepest Wounds: a labor and environmental history of sugar in northeasr Brazil. Chapel Hill: The University of North Carolina Press, 2010, p. 166.

${ }^{26}$ José Barbosa do Nascimento citado por DABAT, Christine Rufino. Moradores de Engenho... Op. Cit., p. 604. 
redação, geral e vaga, "abre perspectivas para a fraude e não aplicação da lei". ${ }^{27} \mathrm{O}$ Estatuto não refletia a complexidade do trabalho e emprego nas plantações de cana de açúcar no Nordeste.

Vários dispositivos poderiam ter sido previstos pelo legislador "a fim de evitar fraudes que a inutilizasse em beneficio do empregador". Em diversos momentos "pode o empregador livrar-se, dentro de uma interpretação da lei perfeitamente aceitável, das obrigações impostas pelo Estatuto e quais quer outras leis reguladoras do trabalho rural". ${ }^{28} \mathrm{Na}$ verdade, não houve uma discussão aprofundada antes de sua votação.

O professor de Direito do Trabalho Carlos Chiarelli, realizou uma crítica detalhada ao ETR, cujos resultados foram publicados no livro Teoria e Prática da Legislação Rural trabalhista, sindical e previdenciária. Todas as principais questões são debatidas no texto. 0 artigo 155, por exemplo, que trata da fiscalização do trabalho rural, autuação e aplicação de multas, possui uma "redação extensa e totalmente defeituosa":

"ETR, Art. 155: A toda verificação em que o fiscal concluir pela existência de violação de preceito legal deve corresponder, sob pena de responsabilidade administrativa, a lavratura do auto de infração. Em se tratando porém, de violação de norma legal recente, o fiscal apenas instruirá o Infrator quanto ao modo de proceder, voltando em segunda visita a verificar o cumprimento do disposto no novo texto legal. Da mesma forma procederá quando se tratar de primeira Inspeção em local de trabalho ou estabelecimento recentemente criado. A aplicação de multa não exime 0 infrator da responsabilidade em que Incorra por Infração das leis penais."

Os argumentos do autor são claros e precisos:

"O que não poderá deixar de ser passível de crítica é a redação do art. 155 que busca evitar de todas as maneiras a aplicação do auto de infração e a consequente sanção econômica ao empregador faltoso perante as leis laborais. Reitera-se a necessidade de funcionar o fiscal como instrutor do patrão, considerando que a lei é recente, que o estabelecimento rural poderá ser de pouco tempo de duração, etc., aspectos que, quando do lançamento da Consolidação [CLT], não foram sequer alvitrados para eximir ou diminuir a responsabilidade do empresário urbano. Houve, assim, intuito desabrido de obstacularizar a imposição de sanções econômicas ao empregador rural inadimplente com os mandamentos legais. No entanto, o legislador procurou usar, para essa política de benemerência, um caminho disfarçado e tortuoso, em que não se fixou valor para as sanções (obrigando ao recurso da analogia) e em que se aconselha os fiscais a agirem como conselheiros, e não como zelosos observadores do cumprimento da norma vigente. Uma política estranha e, quer nos parecer, não muito equânime, em considerando, especialmente, 0 empresariado urbano como termo de comparação."29

${ }^{27}$ PRADO JUNIOR, Caio. "O Estatuto do Trabalhador Rural". In: PRADO JUNIOR, Caio. A Questão Agrária no Brasil. $2^{\circ}$ Ed. SP: Brasiliense, 1979, p. 144.

28 Idem, p. 147.

${ }^{29}$ CHIARELLI, Carlos A. G. Teoria e Prática da Legislação Rural: trabalhista, sindical e previdenciária. Porto Alegre: LIVRARIA SULINA, 1971, pp. 61-62. 
De qualquer ângulo é perfeitamente observável as lacunas inseridas no ETR. A reformulação do artigo 492 da CLT, que versa sobre o direito a estabilidade, por exemplo, não aparenta ter sido acidental, tendo em vista ser bastante comum grandes empresas agroindustriais, como as usinas, possuírem vários estabelecimentos (engenhos).

"CLT, Art. 492: O empregado que contar mais de dez anos de serviço na mesma empresa não poderá ser despedido senão por motivo de falta grave ou circunstância de força maior."

"ETR, Art. 95: O trabalhador rural que conte mais de dez anos de serviço efetivo no mesmo estabelecimento, não poderá ser despedido senão por motivo de falta grave ou circunstância de força maior."

Chiarelli discute:

\begin{abstract}
"Existe uma falha básica na redação do artigo 95 do Estatuto, quando se afirma que o trabalhador rural deve contar mais de 10 (dez) anos de serviço efetivo no 'mesmo estabelecimento', o que é uma monstruosidade, principalmente se colocamos, frente a frente, o disposto no artigo antes mencionado com 0 conteúdo dos artigos 71 e 73 , onde, inclusive, se assinala que 'é lícita a transferência quando ocorre a extinção do estabelecimento' e que 'não se considera transferência a que não acarreta mudança de domicilio'. [...] Assim, se a estabilidade do trabalhador rurícola é obtida no estabelecimento, e não na empresa (isto é, em qualquer dos estabelecimentos que compõem uma empresa), podemos constatar, ajustando as faculdades admitidas nos artigos 70 e 71 (onde se regulamenta a alteração do contrato individual de trabalho rural), que a empresa que conta com mais de um estabelecimento jamais permitirá que um trabalhador chegue a alcançar a estabilidade [...]. Verificam-se, destarte, diversas possibilidades de evitar que os camponeses se estabilizem. E por quê?"
\end{abstract}

Os formulários de acordos de demissão de trabalhadores com mais de dez anos de serviço, que chegaram a Junta de Palmares, mostram o uso proveitoso de todas essas antevistas lacunas. Deixam explícito que o ex-empregado trabalhou em vários engenhos.

A omissão consentida do Estado na "fiscalização do fiel cumprimento dessa lei", não foi fortuita ou eventual. A força política e econômica da classe latifundiária no Brasil - secularmente estabelecida e consolidada, e que não havia permitido a aplicação da CLT no campo -, talvez tenha permitido, ou orquestrado, todo o processo.

Segundo Antonio Callado, "o Estatuto só foi aprovado porque ninguém acreditava que fosse posto a funcionar". ${ }^{30}$ Talvez, seu propósito tenha sido "harmonizar o corpo social para afastar 'a possibilidade trágica da luta de classes'”. ${ }^{31}$ Aprovar uma lei que refreasse uma possível revolução sem obstruir o andamento do sistema, talvez tenha sido a solução ideal, encontrada pela classe latifundiária, com força expressiva em Brasília, para evitar uma possível cubanização ou sinização do país, numa época de convulsões generalizadas.

\footnotetext{
30 CALLADO, Antônio. Tempos de Arraes: a revolução sem violência. Op. cit., p. 114.

31 DABAT, Christine Rufino. "uma 'caminhada penosa': a extensão do Direito trabalhista à zona canavieira de Pernambuco". In: Clio: Revista de Pesquisa Histórica, Recife: EDUFPE, nº 26.2, 2008, p. 296.
} 
"Obviamente, a mobilização dos trabalhadores [...] foi um fator essencial na concretização desses direitos". 32 Porém, o Estado estabeleceu limites às concessões. Aquilo que parecia uma total conquista se mostrou um instrumento poderoso de controle. A legislação trabalhista rural no Brasil foi "um conjunto de regras muitas vezes editadas a contragosto e que atendem, portanto, apenas em parte, aos impulsos das [...] reivindicações de massa. São concessões feitas, passo a passo, sempre na menor medida possível, pelas forças e pelos grupos detentores do controle da economia". 33

Genérica em seus princípios, omissa e obscura em seus propósitos e ineficaz na sua aplicação, talvez o ETR tenha sido propositadamente formulado. Lapso despercebido, ou erro consentido, de fato, estava repleto de falhas. No nível do judiciário, a Justiça do Trabalho, por meio das Juntas de Conciliação e Julgamento, parece confirmar as ideias acima levantadas. Seu princípio de conciliação, na prática, garantia a classe patronal o descumprimento parcial da legislação trabalhista.

"Conciliar significa, à primeira vista, ceder sempre direito adquirido". 34 "O empregado sempre perde ao fazer a conciliação" ${ }^{35} 0$ que seriam as conciliações se não a renuncia parcial de direitos? Receber (parcialmente) o que pertencia à classe trabalhadora - por direito - era um ganho? Na visão daquele que deixa de ser totalmente indenizado, o calculo básico dessa equação deveria ser feito com base na subtração: quanto se deixou de receber, ou quanto se perdeu com as "conciliações"? Receber aquilo que já lhe pertencia representava, aos trabalhadores, um ganho?

\begin{abstract}
"Além disso, a história não era muito mais promissora para aqueles trabalhadores que, de boa-fé, levavam suas queixas aos tribunais do trabalho. Ineficiência administrativa, tribunais superlotados e uma tendência para a 'conciliação' frequentemente produziam 0 que pode ser denominado de 'justiça com desconto'. Mesmo quando ganhava um caso legal, um trabalhador brasileiro era forçado a um acordo com seus patrões, obtendo um valor muito menor do que 0 inscrito em seus direitos legais, caso contrário teria de enfrentar atrasos intermináveis devido aos apelos da empresa - que algumas vezes se estendiam por até 12 anos." 36
\end{abstract}

A Justiça do Trabalho permitia que parte dos direitos fosse legitimamente descumprido. Seu funcionamento acabava legalizando a precariedade das relações de trabalho, mantendo 0

\footnotetext{
32 Idem, p. 306.

33 ROSA, F. A. de Miranda. Sociologia do Direito: o fenômeno jurídico como fato social. $9^{a}$ Edição, Rio de Janeiro: Jorge Zahar, 1992, p. 139.

34 SOUSA, Ester Maria Aguiar de. Juntas de Conciliação em Julgamento: um estudo da eficácia da Justiça do Trabalho, em estudos de caso nas JCJ de Recife. Dissertação de Mestrado. UFPE, 1984, p. 128.

35 Idem, p. 134.

${ }^{36}$ FRENCH, John D. Afogados em Leis: a CLT e a cultura política dos trabalhadores brasileiros. São Paulo: Editora Fundação Perseu Abramo, 2001, p. 19.
} 
nível salarial reduzido. Talvez seja com negativas que se deva afirmar a prática da Justiça do Trabalho. As Juntas não eram exteriores a um sistema tradicional de dominação. Seus efeitos não foram nem transformador da realidade que ela visava (em princípio) modificar, nem educador das atitudes patronais. As Juntas de Conciliação e Julgamento não corrigiam as seculares desigualdades na zona canavieira de Pernambuco. Tratava-se de uma desigualdade pensada, organizada, legalizada e em certa medida homologada pela Justiça do Trabalho. ${ }^{37}$ Longe de representar acesso à cidadania e inclusão social, sua função talvez tenha sido, apenas, dar uma solução legal para conflitos sociais que poderiam ter finais catastróficos para os interesses capitalistas.

O historiador John French utilizou a expressão "afogados em leis" para se referir ao estado em que se encontrava a classe trabalhadora. ${ }^{38}$ Sem garantias obvias de cumprimento do ETR pela classe patronal canavieira, com fiscalização do trabalho inexistente e Justiça do Trabalho "conciliadora", não restavam mais alternativas aos canavieiros.

Com nível de remuneração abaixo do mínimo vital, regime de trabalho forçado e sem perspectivas de melhoras, os canavieiros sentiriam no corpo as marcas da (in)Justiça. O Estado, omisso em certos momentos e conivente em outros, representava o último elemento patógeno a compor a arquitetura anunciada de fome e doenças dos trabalhadores. 39

As especificidades históricas que marcaram as condições de vida da maior parte dos trabalhadores rurais nas plantações açucareiras no Nordeste do Brasil traduzem uma realidade distinta da vida urbana. Mesmo reações individuais e coletivas na Justiça do Trabalho eram limitadas por estruturas seculares de dominação e violência.

O funcionamento da Justiça do Trabalho na Zona da Mata de Pernambuco revela os limites da resistência dos trabalhadores. A ideia de que os indivíduos sempre negociam e fazem escolhas frente ao poder encontrou barreiras quase intransponíveis na zona canavieira de Pernambuco. A tese de que a legislação trabalhista mostrou-se instrumental para que os trabalhadores articulassem suas exigências parece ter sido válida, sobretudo, para a história social da classe operária.

\footnotetext{
37 Para mais detalhes ver FERREIRA FILHO, José Marcelo Marques. "Entre 'Direitos' e 'Justiça': os trabalhadores do açúcar frente à Junta de Conciliação e Julgamento de Escada/PE (1963-1969)". In: Cadernos de História: oficina de História: trabalhadores em sociedades açucareiras. Recife: EdUFPE, ano 6, nº 6, ISSN 1807-9229, 2009.

${ }^{38} \mathrm{FRENCH}$, John D. Afogados em Leis: a CLT e a cultura politica dos trabalhadores brasileiros. Op. Cit.

39 FERREIRA FILHO, José Marcelo Marques. "Malandragem e Corpo Mole': a naturalização das doenças do trabalho no discurso da classe patronal canavieira em Pernambuco (1960-1975)". In: Cadernos de História. Oficina de História: escritos sobre saúde, doenças e sociedade. Recife: Ed. Universitária da UFPE, ano 7, $n^{\circ} 7$, ISSN $1807-$ 9229, 2010.
} 
Mais uma vez, não se trata de subestimar o papel dos trabalhadores e suas organizações frente à classe patronal e ao Estado, mas perceber que as peculiaridades histórias de cada contexto permitem determinados contornos possíveis apenas em alguns casos específicos. Dessa forma, a análise de centenas de processos iniciados contra usinas e engenhos da Zona da Mata de Pernambuco contribui primeiro para retirar os trabalhadores rurais do hall dos povos sem consciência, sem classe; e depois para mostrar que mesmo a consciência e a ação efetiva não são suficientes para afirmar sua hegemonia. Para compreender os trabalhadores nos seus próprios termos é preciso, então, entender a classe trabalhadora fora dos limites urbanos e, em seguida, compreender que realidades distintas condicionam histórias distintas. 